\title{
KEHUJJAHAN AS SUNNAH DALAM \\ MENGISTINBATKAN HUKUM ISLAM
}

Oleh : Ramli Makatungkang

\begin{abstract}
Abstrak
Kehujjaan As Sunnah dalam mengistimbatkan hukum menempatkan pada posisi kedua sesudah Al-Quran. Sunnah sebagai hujjah dalam mengistimbatkan hukum terbagi atas tiga yaitu sunnah Qauliyah (perkataan nabi) yaitu hadis Rasul yang beliau sampaikan dalam berbagai tujuan yang membuat berbagai maksud syariah baik yang berkaitan dengan Aqidah Akhlak maupun yang. Lainnya. Kedua sunnah Fi'liyah ( perbuatan nabi) segala peraturan pekerjaannya yang dipahami dan dilakukan nabi untuk diikuti umatnya sampai kepada umat akhir zaman. Dan yang adalah sunnah Tagririyah yaitu sunnah seseorang melakukan sesuatu perbuatan atau mengemukakan suatu ucapan kepada nabi dan nabi mengetahui apa yang dilakukan ocang ito dan mampu menyangga namun nabi diam dan tidak menyangga nya maka hal ini merupakan pengakuan nabi.Fungsi Sunnah terhadap Al-Quran untuk menjelaskan kepada umat Islam ajaran-ajaran yang diturunkan Allah melalui Al-Quran.
\end{abstract}

Kata kunci : Hujjah, sunnah, istinbat, hukum islam

\section{PENDAHULUAN}

A. Latar Belakang

Sebagian besar dikalangan umat Islam terdapat perbedaan dalam memahami pengertian sunnah dan Hadits. Bahkan dikalangan para intelektual muslim sendiri masih juga terjadi hal tersebut. Dapat kita lihat sebagai contoh dengan perbedaan pendapat yang terjadi diantara ulama hadis dan ulma usul ficiih tentang bagaimana pembahasan sabda Rasulullah saw dalam menetapkan hukum. ${ }^{1}$ Hal seperti itu tidak harus menyebabkan setiap orang muslim selalu bermasa bodoh dan menjadi pengikut tanpa mengetahui keberadaan dan kejelasan yang sebenamya.

${ }^{1}$ Lihat Thalib Muhamad, Cara menyelesaikan Pertenlangan Hadis dan Al Duran, Cet. I Bandung : PT Al Maarif : 1979, h.7. 
Umat Islam sudah mahfum dan menyepakati terhadap posisi sunnah sebagai sumber istimbat dalam pengambilan hukum Islam kedua setelah al-Quran. Sunnah berfungsi sebagai penopang Al Quran dalam menjelaskan hukum-hukum syarah karena itulah As-Syafii dalam menerangkan Al Quran dan As Sunah tidak menguraikan secara terpisah. Keduanya merupakan satu ke-satuan dalam kaitan dengan kepentingan dan dipandang sebagai sumber yang pokok dan satu yakni Nash, keduanya saling menopang secara sempurna dalam menyelesaikan masalah syarah. ${ }^{2}$

Menyikapi kehujjahan sunnah kearah pemahaman yang sempurma, merupakan suatu keharusan untuk mengetahui lebih dalam tentang kehujjaan assunnah dan dalam kondisi yang bagaimana digunakan untuk mengistinbath-kan hukum. Dalam al-Qur'an Allah memerintahkan kepala kita untuk mengembalikan persoalan pada a!-Qur'an dan menyelesaikan suatu persoalan Allah berfiram dalam al-Qur'an surat An-nisa : 59 yang berbunyi :

"Hai orang-orang yang beriman taatilah Allah dun taatilah Rasul dan Ulil Amri diantara kamu, kemudian jika kamit herlainan pendapat tentang sesuatu, maka kembalikan kepada Allah clan rasulnya. ${ }^{3}$

Keberadaan sunnah yang didapati oleh umat Islam sekarang ini sudah berbentuk sebuah produk yang dihasilkan oleh perjalanan ijtihad ilmiah para pembukuannya didalam banyak hal terdapat batu sandungan perbedaan pendapat contoh dua kitab sunnah yang termahsyur saat sekarang ini yang kita pakai yaitu kita Bukhari dan Muslim.

Karena keingitahuannya kurang, bisa saja tanpa disadari kita banyak mengamalkan hadis-hadis palsu yang banyak beredar atau mungkin kita jadi pesimis dan menghindari kehujjaan assunnah sebagai salah satu sumber hukum dalam agam Islam. Golongan yang seperti ini memang tidak ditemukan pada zaman Rasul dan Khulafa Urasyidin serta pada zaman Bani Ummayah, tetapi nanti pada masa Abbasiyah barn muncul secara jelas sekelompok kecil umat Islam yang menolak as-Sunah sebagai salah satu sumber ajaran Islam tetap besar jumlahnya. Dalam menempatkan posisi sunnah mereka telah banyak mengembankan upaya penelitian yang mendalam, membuat berbagai macam istilah

\footnotetext{
${ }^{2}$ Lihat Muhammad Abu Zahra Ushul Al Figih, Diterjemahkan Oleh Saifullah Ma'sim, Slamet Basyir, Hamid Ahmad Rasyid, Ali Zawawi, Cet II Jakarta : Pustaka Firdaus : 1974, h. 151

${ }^{3}$ Departemen Agama R.I. al-Qur'an dan terjemah Jakarta : Yayasan Penterjemah al-Qur'an : PT. Inter Massa : Lth. H. 128.
} 
merumuskan kaidah-kaidah meletakkan metode-metode dan menyusun disiplin ilmu ang dapat digunakan untuk mempelajari sunnah, sehingga kesungguhan mereka tersebut telah membuahkan hasil karya yang monumental dan dapat dipertanggung jawabkan secara ilmiah. ${ }^{4}$ Gerakan-gerakan penelitian mencakup banyak kajian yang jalam pemecahan masalahnya yang ditempuh para Ulama tentang cara yang berbedabeda, tetapi bukan berarti hasilnya berbeda pula. Salah satu contoh tentang hal ini bagaimana pada Ulama menyelesaikan masalah ketika menemukan hadis yang saling bertentang satu dengan yang lain. Hal ini umumnva Ulama menggunakan tiga macam cara yaitu: at-Taufiq dan al-Tautiq. Hasilnya dipertemeukan banyak kesamaan. ${ }^{5}$

Para Ulama juga berbeda pendapat tentang adanya hal-hal berupa kelalaian siperawi dan kealpaannya sekalipun mereka dan kita tidak pernah menemukan hal serupa dengan itu. Hal ini ditemukan ketika para Ulama mengeluarkan argumen tentang keshahihan hadis ahad.

Perbedaan yang demikian tidak hanya didapati dalam masalah, tetapi sangat banyak didapati dalam berbagai kajian bidang hadis lainnya dan hal ini jelas menjadikan bagian yang sangat penting untuk dikaji kejelasannya.

Metodologi pemahaman dan penetapan hukum Islam terhadap masalah yang dihadapi dalam lingkungan masyarakat muslim. ${ }^{6}$

Dengan demikian dapat diketahui betapa pentingnya upaya bagi setiap muslim untuk mengetahui seluk beluk ijtihad para Ulama dan aspek permasalahannya dal am kai tan nya dengan kedudukan sunnah sebagai sumber hukum kedua setelah al-Quran. Hal inilah yang mendorong penyusun untuk meneliti lebih jauh tentang kehujjaan sunnah dalam mengistinbath-kan Hukum Islam.

B. Rumusan Masalah

Yang menjadi masalah dalam oenelitian ini adalah sebagai berikut :

${ }^{4}$ Ibid.h.15.

${ }^{5}$ Ibid.h.113.

${ }^{6}$ Mustafa Al-Siba'I, Sunnah dan Peranannya Dalam Penetapan Hukum Islam, Sebuah Pembelaan kaum Sunni, Pentedernah Nurcholis Madjid, Cet. I, Jakarta : Pustaka Firdaus : 1991, h. 209. 
1. Bagaimana metodologi dan kehujjaan sunnah dalam menQ-istinhath-kan Hukum Islam?

2. Bagaimana permasalahan sunnah dalam penetapan hukum Islam ?

C. Tinjauan Pustaka

Sekarang ini banyak cenderung para ilmuwan Islam didalam melakukan pengkajian hukum secara kontemporer. Didalam memahami syari'at yang dibawa 3leh Rasul para Ulama mengadakan pendekatan baik secara kaidah pembahasan dan melalui pendekatan magashid al-syari'ah tujuan syari'at dalam mengistinbathkan hukum. Pendekatan ini penekanannya terletak pada upaya mengkaji dan menjelaskan hukum dari suatu kasus yang dihadapi melalui pertimbangan maksud-maksud svara' dalam mengistinbathkan hukum. Teori yang digunakan menjelaskan hukum dalam berbagai kasus yang ada nash maupun hadis.

Untuk menuju ke arah perbaikan hukum maka rujukan pengambilan hukum harus diperhatikan apalagi yang $\mathrm{b}$ erkaitan dengan sumber hukum assunnah yang sekarang ini dalam pengamalannya mengambil hadis-hadis yang tidak memenuhi syarat dalam keshalihan hadis. Dengan demikian salah satu syarat dalam penelitian ini, daspat mengetahui metodologi kehujjaan sunnah dan bagaimana permasalahan yang ada didalamnya.

D. Tujuan Penelitian

Sebagaimana permasalahan diatas, maka yang menjadi tujuan penelitian adalah sebagai berikut :

1. Untuk mengetahui bagaimana metodologi untuk mencapai kehujjan sunnan dalam mengistinbatkan Hukum.

2. Untuk mengetahui hal-hal apa yang menjadi permasalahan as-sunnah dalam penetapan hukum Islam.

E. Kegunaan Penelitian

Hal-hal yang menjadi sasaran dan kegunaan dalam penelitian ini adalah sebagai berikut :

1. Dapat menghilangkan keragu-raguan umat Islam untuk dijadikan assunnah sebagai sumber dalam penetapan hukum.

2. Dapat membantu kita untuk memahami lebih dalam terhadap selukbeluk perniasalahan sunnah dalam hubungannya dengan mengistinbathkan hukum. 
3. Untuk mengetahui metodologi dari berbagai macam sunnah yang bisa digunakan dalam mengistinbathkan hukum.

F. Metodologi Penelitian

Dalam penelitian ada beberapa hal yang perlu kita kembangkan :

1. Metode pendekatan yang digunakan adalah pendekatan yuridis yang dan histories meneliti perkembangan dari segi hukum yang mengaturnya dan sejarah mendukung perkembangan tersebut.

2. Metode Pengumpulan Data Penulis mengadakan penelitian kepustakaan yang berhubungan dengan pembahasan dalam penelitian ini.

3. Metode Pengolahan Data Peneliti menggunakan metode kualitatif dengan jalan mengumpulkan data dan dibahas berdasarkan mutu bahasan yang dapat dijadikan rujukan.

4. Metode Analisa, untuk mencapai penelitian yang diharapkan penul ia menggunakan metode analisa baik yang bersifat Deduktif, induktif serta komparatif.

\section{SUNNAH SEBAGAI SUMBER HUKUM}

\section{A. Pengertian Sunnah}

Kalau melihat pengertian As sunnah dari seti etimologi as sunnah berarti Jalan. ${ }^{7}$ Hal ini sebagaimana yang terdapat dalam Al Quran S. An Nisa 26. "Allah hendak menerangkan hukum kepadamu, dan menunjukimu kepada jalan orang sebelum kamu (para nabi dan shalihin) dan hendak menerima taubatmu. Dan Allah maha mengetahui lagi maha bijaksana". 8

\section{B. Macam-Macam As-Sunnah}

Dari pengertian yang dijelaskan diatas maka oleh para ahli .usul membagi sunnah itu kepada tiga yaitu :

a. Sunnah Qauliyyah (Perkataan Nabi) Yaitu Hadis-hadis Rasul Saw yang beliau katakana dalam berbagai tujuan dan konreks yang memuat berbagai maksud Syara'

\footnotetext{
${ }^{7}$ Mustafa Al-Siba'I Sunnah Dan Peranannya Dalam Penetapan Hukurn Islam, -Penterjemah Nurcholis Madjid, Cet I (Jakarta, PT Pustaka Firdaus, 1991) h. 1.

${ }^{8}$ Departemen Agama, Quran dan Terjemah, (Jakarta, Yayasan Penyelenggara penterjemah, PT Intermasa, 1993) h. 121
} 
baik yang berkaitan dengan aqidah, akhlak, maupun yang lainnya. Contoh Rasul Bersabda dalam Hadisnya sebagai berikut : "Dari Ibnu Abbas, dari nabi Saw apabila seseorang kaum is hendak hersetuhuh dengan isterinya bacalah Dengan mum Altah. Ya Tuhan jauhkanlah syaitan clari pada kamu dari pada anak yang engkau anugerahkan kepada kami, kalau terjadi anak dengan persetubuhan itu niscaya syetun tidak akan memberi bahaya kepada anak itu menjadi anak yan balk. Buchari". 9

b. Sunnah Fi'liyah (Perbuatan Nabi Saw) Segala perbuatan Rasul atau pekerjaannya yang dipahami dan dilakuan nabi diikuti umatnya sampai kepada kita. Salah satu contoh dari sunnah ini adalah : "Dari Aisyah Isteri nabi Saw . sesungguhnya nabi Saw, apabila mandi karena Janaba dimulainya membasuh kedua belah tangannya, lalu is berwudhu sebagaiaman wudhunya untuk sembahyang, kemudian itu dimasukkan anak jarinya kedalam air dan digosokannya pangkal rambut kepalanya. Kemudian dituangkannya keatas kepalanga tiga sauk air dengan kedua belah tangannya, dan dituangkannya air kepada segenap tubuhnya". ${ }^{10}$

c. Sunnah Tagririyah, Bila seseorang melakukan suatu perbuatan atau mengemukakan suatu ucapan dihadapan nabi atau pada masa nabi, nabi mengetahui apa yang dilakukan orang itu dan mampu menyangganya, namun nabi diam dan tidak menyanggahnya, maka hal ini merupakan pengakuan dari nabi. Keadaan diam nabi itu dapat dibedakan dalam dua bentuk: Pertama, nabi mengetahui bahwa perbuatan itu pernah dibenci dan dilarang oleh nabi. dalam hal ini kadang-kadang nabi mengetahi bahwa sipelaku tarjih. Umpamanya pada suatu waktu nabi melipat kedua tangannya dibawah dada pada waktu berdiri sedang shalat, dan pada waktu lain meluruskan tangannya dibawah. Dalam hal ini tidak dapat dikatakan ada pertentangan antara dua perbuatan nabi, sehingga dikatakan bahwa perbuatan yang dilakukan beliau kemudian membatalkan atau mensahkan apa yang dilakukan nabi sebelumnya. Bila nabi melakukan suatu perbuatan yang bukan merupakan penjelasan terhadap sebelumnya, tidak ada pula dalil yang menunjukkan bahwa perbuatan itu khusus untuk nabi, tetapi dapat diketahui sifat perbuatan wajib, nadab atau mubah. Melalui penjelasan langsung dari nabi atau tidak maka mayoritas ulama figih dan kalam sepakat mengatakan bahwa

\footnotetext{
${ }^{9}$ Imam al-Buchari di terjemahkan oleh Zainuddin Hamidy (Jakarta Cet, 4 Widjaya 1954), h. 13.

${ }^{10}$ Imam Al-Buchari, op.cit, h. 101
} 
umat dituntut mengikuti perbuatan itu baik yang berbentuk baik, nadab atau ibadah. Kedua, bentuk perbuatan tersebut berlaku secara umum untuk nabi sendiri maupun untuk umatnya. Perbuatan nabi yang dapat diketahui merupakan penjelasan hukum untuk umat dan menjadi dalil hukum yang harus dipatuhi oleh umat dalam hal ini tidak ada perbedaan pendapat dart ulama semua sepakat. Penjelasan dalam bentuk ini adalah yang dikemukakan Nabi dengan ucapan yang jelas, seperti sabda Nabi : "Sholatlah kamu sebagaimana kainu melihat saya sholat".

\section{Fungsi Sunnah}

Rasulullah Saw sebagai pembawa risalah Allah berfungsi untuk menjelaskan kepada umat Islam ajaranaj aran yang diturunkan Allah melalui alQuran. Hal ini sesuai dengan finnan Allah dalam surat An-Nahl (16) : 44 "Kami turunkcm kepada engkau Al-Quran agar engkau jelaskan kepada umat manusia apa-apa yang diturunkan kepuda mereka"11

Sunnah Rasulullah adakalanya berbentuk pendukung hukum-hukum yang ada dalam AlQuran, seperti sunnah. Rasul tentang kewajiban Shalat, zakat, dan haji. Kewajibankewajiban ini telah Lida dalam Al-Quran, kemudian Rasulullah memperkuatnya dengan Sunnah beliau adakalanya sunnah menjelaskan hukum-hukum yang ada dalam Al-Quran, kemudian Rasulullah memperkuatnya dengan Sunnah beliau. Adakalanya sunnah menjelaskan hukumhukum yang ada dalam Al-Quran penjelasan Rasulullah terhadap AlQuran ada beberapa bentuk yaitu :

1. Merinci hukum global yang ada dalam Al-Quran, seperti kewajiban sholat yang a da dalam Al-Quran yang sifatnya global, karena tidak memerinci bebherapa kali, berapa rakaat, dan bagaimana tata caranya.

2. Menjelaskan hukum mutlak yang ada dalam Al-Quran seperti potong tangan orang yang melakukan tindak pidanan pencurian perintah Allah ini tidak menjelaskan ukuran yang dipotong yang nisab harta yang dicuri yang dikenakan hukum potong tangan.

3. Mengkhususkan hukum-hukum yang bersifat umum dalam al-Quran seperti tentang pembagian harta warisan.

D. Khujaan Sunnah

Para ulama sepakat mengatakan bahwa sunnah rasul dalam bentuk fi-liyah, qauliyah dan tagrifiyah merupakan sumber asli dari sumber hukum syara dan menempati

${ }^{11}$ Depertemen Agama R.I. Al-Qur'an Terjemah, h. 408 
posisi kedua sesudah al-Quran. Ada beberapa alasan yang dikemukakan ulama usul fiqih untuk mendukung hal tersebut antara lain :

1. Al-Quran Surat Ali Imran 31 : "Apabila mencintai Allah maka ikutilah aku, Allah akan mencintaimu".

2. Surat Al Ahzab 21 : "Sesungguhnya pada dirt Rasulullah itu bagi kannt teladan yang baik vault bagi orang yang mengharapkan Rahmat Allah dan kedatangan Hari Kiamat dan dia hanyak menyebut Allah".

3. Surat Al Hasyr 7 : "Apa yang diberikan Rasul kepaclannt maka ambilah dan apa yang dilarang bagimu maka tinggalkanlah”.

E. Fungsi Sunnah Terhadap Al-Quran

Rasulullah sebagai pembawah Risalah berfungsi menjelaskan kepada umat Islam ajaranajaran yang diturunkan Allah melalui Al-Quran. Dalam hal kedudukan sunnah dalam- Al-Quran para ulama usul fiqih berpendapat bahwa hanya tiga ada tiga hal kedudukan dalam Al-Quran dart segi hukumnya antara lain sebagai berikut :

1. Sunnah menjelaskan ayat-ayat A1- Quran yang sifatnya global, mentakhsiskan ayat yang umum atau merinci ayat-ayat yang mujmal. Hal ini sejalan dengan telah diberikan oleh Allah kepada Rasulullah yaitu hak untuk memberikan penjelasan ayatayat Al-Quran kepada umat manusia.

2. Sunnah membawah hukum yang tidak ada ketentuan nasnya dalam AlQuran seperti pengharaman binatang buas yang bertaring dan jenis burung yang bercakar tajam serta pengharaman memakai kain sutra. ${ }^{12}$

3. Sunnah berfungsi menetapkan hukum yang telah termuat dalam AlQuran. Oleh karena itu hukum menjadi dua sumber atau dua dalil yaitu dalil yang menetapkan dari ayat-ayat Al-Quran dan dalil yang mengkukuhkan dari sunnah antara lain shalat, haji dan zakat serta puasa. $^{13}$

\section{JENJANG SUNNAH DALAM MENGISTIMBATKAN HUKUM}

\section{A. Kualitas As Sunnah}

Ditinjau dari segi kualitasnya, hadis atau as sunnah terbagi dalam dua bagian.

a. Hadis Makbul

\footnotetext{
12 Abdul Wahab Khalaf. Op.cit. h. 48

13 Ibid.
} 
Menurut bahasa makbul berarti ma'kuz (yang diarnbil) dan mushadaq (yang dibenarkan atau diterima). Sedangkan dalam pemehaman menurut istilah adalah: "Hadis yang telah sempurna padanya, syarat-syarat penerimaan. ${ }^{14}$

b. Hadis Mardud

Menurut bahasa mardud berarti 'yang ditolak' atau diterima, sedangkan mardud menurut istilah adalah Imam Syafii, maka Ijma pendapat-pendapat sahabat dan Qiyas merujuk pada kedua sumber tadi. Imam Syafii menerima hadis ahad sebagai hujjah, tetapi syratnya harus dari perawi yang dapat dipercaya dan memenuhi kriteria tam al dhabit. Hadis mursal juga diterima dengan syarat periwayatnya banyak berjumpa sahabat nabi dan sanadnya dapat dipercaya posisi dan hadis mutawir lebih tinggi dari hadis ahad, mursal dan hadis musnad.

c. Perawinya tidak menyalahi ahli ilmu yang meriwatkannya hadis yang sama. ${ }^{15}$

B. Sunnah Yang Dapat Dijadikan Hujjah

Dalam penjelasan diatas telah dibahas tentang pembagian kualtias hadis secara umum, yang terbagi pada hadis shahih, hadis hasan, dan hadis daif dan pembagian hadis menurut kualitas, yang dibagi dalam ketiga bagian juga yaitu hadis mutawatir, hadis ahad dan hadis mahsyur. Secara tegas dapatlah dikatakan disini bahwa hadis atau as sunnah yang dapat dijadikan hujjah :

1. Darii segi kualtiasnya :

a. Hadis shahih

b. Hadis hasan

2. Dari segi kualitasnya :
a. Hadis mutawatir
b. Hadis mahsyur
c. Hadis musnad

\section{PENUTUP}

Kesimpulan

\footnotetext{
${ }^{14}$ Munzier suparta, Ilmu Hadits, (Jakarta, PT Raja Grafindo Persada, 1993) h. 107

${ }^{15}$ Ibid h. 22
} 
Dari hasil penelitian tentang kehujjaanAs-Sunnah dalam Menginstinbatkan hukum Islam maka peneliti membuat kesimpulan sebagai berikut :

1. Kehujjaan As Sunnah dalam mengistimbatkan hukum menempatkan pada posisi kedua sesudah Al-Quran.

2. Sunnah sebagai hujjah dalam mengistimbatkan hukum terbagi atas tiga yaitu sunnah Qauliyah (perkataan nabi) yaitu hadis Rasul yang beliau sampaikan dalam berbagai tujuan yang membuat berbagai maksud syariah baik yang berkaitan dengan Aqidah Akhlak maupun yang. Lainnya. Kedua sunnah Fi'liyah ( perbuatan nabi) segala peraturan pekerjaannya yang dipahami dan dilakukan nabi untuk diikuti umatnya sampai kepada umat akhir zaman. Dan yang adalah sunnah Tagririyah yaitu sunnah seseorang melakukan sesuatu perbuatan atau mengemukakan suatu ucapan kepada nabi dan nabi mengetahui apa yang dilakukan ocang ito dan mampu menyangga namun nabi diam dan tidak menyangga nya maka hal ini merupakan pengakuan nabi.

3. Fungsi Sunnah terhadap Al-Quran untuk menjelaskan kepada umat Islam ajaran-ajaran yang diturunkan Allah melalui Al-Quran.

4. Hal-Hal pokok yang ada dalam sunnah dalam mengistinbatkan hukum adalah :

a. Hadis yang digunakan hams dari kitab yang asli.

b. Sanad dan Matan harus sesuai dengan kaidah mayor dan minor.

c. Harus menguasai ilmu hadis Riwayah dan Dirayah

5. Sunnah yang dapat dijadikan hujjah dalam mengistimbatkan hukum dari segi kualitas hadis shahih dan hasan. Sedangkan dari segi kualitas adalah hadis mutawatir, musynad dan hadis mahsyur. 


\section{DAFTAR PUSTAKA}

Al-Qur' an

AbuZahrah, Muhammad, Ushul Fiqh, diterjemahkan oleh Saifullah Ma'shum, Cet. II: Jakarta : PT. Pustaka Firdaus, 1994.

Al-Bukhari Muhammad ban Ismail, Shahihul Bukhari, diterjemahkan oleh H. Zainuddin Hamdi, Jilid I, Cet. IV, Jakarta : Edjaya; 1954.

Al-Nawawi, Abu Zakaria Yahya bin Yusuf, Shahih Muslim bi Syarhm al-Nawawi, Juz II, Mesir; alMathabar al-mishiriyyah, $248 \mathrm{H}$.

A, Hanafi, Ushul Fiqh, Cet. V, Jakarta: Widajya; 1971.

Anwar Haijono, Hukum Islam Kekuasaan dan Keadilan, Cet. I, Jakarta : Widajaya, 1973.

Abdul Wahhab Khallaf, Ushul Fiqh, diterjemahkan oleh H. Mob. Zuhri dan Ahmad Sarib, Cet. I, Semarang : Bina Utama, 1994.

Ahmad bin Ali bin Hijr al-Asqalani, Fath al-Bari, Jilid IV, Beirut: Dar alFikr wa martabah al-salafiyah; a.th.

Ismail H.M. Suhudi, Kaidah Keshashihan Sanad dan Hadis, Cet. I, Jakarta; PT. Bulan Bintang: 1992. Metodologi Penelitian Hadis Arabi, Ce-t. I Jakarta : PT. Bulan-Bintang; 1992.

- Hadis Nahi Alemirut Pembela, Penginkar dan PernaIsu, Cet. I Jakarta : Gema Insani Press: 1995.

Munzier Suparta dan Mang Ranuwijaya, Ilntu Hadi.s, Cet. I, Jakarta : PT. Perasada; 1995.

Muhammad bin AhrnirA1tsribubi, ahkam al-Qur'an, XVIII. Kairo: Dar al-Katib al' Arabi; 1387 , h. 1967 M.

Muhammad Rasyid Ridha, This'll- al-Qur'an al-Hikam ('TafSir Juz III, Beirtu; Dar alMa;arit 1939 h1973 M.

Muhammad Asad, Islam di Simpang Jalan, t.tmp., t.p., t.th,

Muhammad Thalib, Cara Menyelesaikan Pertenlangan Hadis dan alOur'an, Cet. I, Bandung : PT. AlMa'arif ; 1979.

Mustafa as-Sibaj, Sunnah dan Peranannya dalam Penetapan Hukum Islam Sebuah Pembelaan Kaum Sunni, penterjemah Nurcholis Madjid. Prof. DR., Cet.. I. Jakarta: P. Pustaka Firdaus.

T.M. Hasbi Ash-Shiddiqy, Kriterian Antara Sunnah Bid'ah, cet VI, Jakarta: PT. Bulan Bintang. 1983 